\title{
Eduard Friedrich Wilhelm Pflüger and the Nobel Prize
}

\author{
Bernd Nilius
}

Received: 20 June 2014 / Accepted: 25 June 2014 / Published online: 6 August 2014

(C) Springer-Verlag Berlin Heidelberg 2014

Imagine the following: the Editor in Chief of a relatively small scientific journal with a half decent Impact Factor receives the Nobel Prize for her/his research work on a topic that has attracted most of the submissions to this journal. Would this impact the journal? Would the number of submissions increase? Would the quality of the submitted papers improve? In all likelihood, the content of this journal would be shaped by the research topic pursued by the lucky Nobel Prize laureate. But what else would happen? Obviously, the Nobel Prize would not have a negative impact on the journal in question. We now know, from the released files of the Nobel committee from the beginning of the last century, that the founder (let us call him the Editor in Chief) of our European Journal of Physiology was short-listed for the 1908 Nobel Prize in Physiology or Medicine and that he was probably not awarded by it because of a not very knowledgeable review by one of the committee members. Yes, this unlucky man was Eduard Friedrich Wilhelm Pflüger, who, in 1868, founded the Archiv für die gesammte (sic) Physiologie (now still known as Pflügers Archiv—European Journal of Physiology, the oldest physiology journal worldwide) Fig. 1. This story [7] reads a bit like a human tragedy [7]. Probably, Pflüger did not know about this and even if he had known something, it would not have affected him very much. He was a fighter, a strong personality, known for his very critical, often harsh and always honest scientific comments, addicted to science, and not to the honors given to some of the luckier physiologists. Probably not a man thirsty for fame, he may well fit the description that "[ $\mathrm{t}]$ he Nobel medallion is etched with human frailties" [5]!

B. Nilius $(\square)$

Laboratory of Ion Channel Research, Department of Cellular and

Molecular Medicine, KU Leuven, Campus Gasthuisberg,

Herestraat 49, bus 802, Leuven 3000, Belgium

e-mail: bernd.nilius@med.kuleuven.be
We will learn more about the founder of our journal in this colorful review [7]. Pflüger was born in the small German city of Hanau on June 7, 1829. Likely shaped in no small part by the passionate political attitudes of his father, he grew up as a fervent democrat and was even arrested for his political activities at the University of Göttingen along with several of his rebellious fellow students [9]. He studied medicine and focused on physiology under the best of its teachers such as Johannes Müller, Hermann Helmholtz, and Emil du BoisReymond, the latter of whom can rightfully be considered one of the fathers of electrophysiology! Pflüger became a professor of physiology in 1859 at the University of Bonn, where he stayed for the rest of his life, becoming an honorary citizen of the town and receiving the royal medallion of the Order of the Pour le Mérite. What about the Nobel prize? Pflüger made many seminal contributions to physiology; to name but a few: in sensory physiology, electrophysiology, and the function of the gut, as well as having performed extensive research on glycogen and invented several physiological instruments. For electrophysiologists, his main contribution is certainly the study of the so-called electrotonus and the formulation of "Pflüger's law" (Pflüger's Zuckungsgesetz), i.e., the result of his research on electrical stimulation and its correlation to muscular contraction, which still reflects some of the key features of voltage-dependent sodium channels. It is surprising that it is not this work that was reviewed for the Nobel Prize. Pflüger's three laws of polar excitation describe: (1) in a muscle innervated by the sciatic nerve a "make contraction" always starts from the cathode (Kathodenschliessung), (2) a "break contraction" always starts from the anode (Anodenöffnung), (3) the weakest current excitation occurs at "make" since a make stimulus is always more effectual than a "break" stimulus [4, 10] (for a concise description, see also pages 133 and 134 in the first electrophysiology textbook by another "father" of electrophysiology, Julius Bernstein [1]). We now know that the "make 


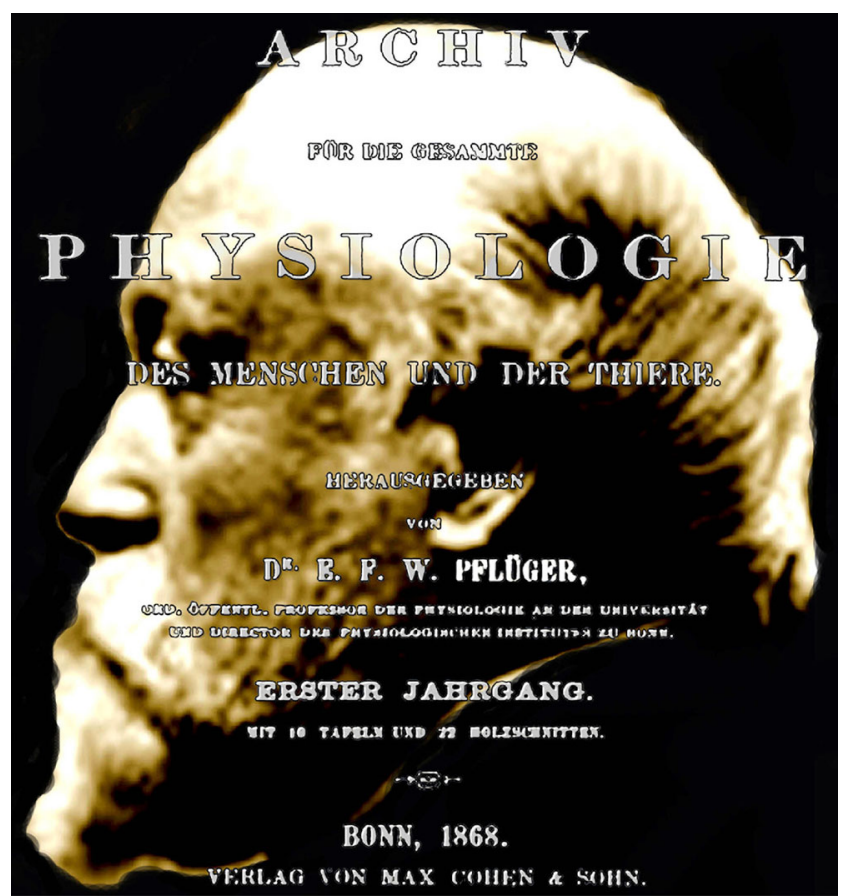

Fig. 1 In a combination of images, Eduard Friedrich Wilhelm Pflüger (1829-1910) is shown as the backdrop to the title page of the first volume of what became known as his Archiv für die gesammte Physiologie now Pflügers Archiv-European Journal of Physiology [from 11]

contraction" is just a depolarization which moves the voltage sensor in the S4 domain of (in Pflüger's preparation probably) the sodium channel $\mathrm{Na}_{\mathrm{v}} 1.6$ (gene SCN6A [3]) and opens the channels by a mechanism still not completely understood. The anode "break" removes a hyperpolarization at which more channels are moved out of the inactivated state and eventually activated by the depolarization following the removal of hyperpolarization. This work is one of the pioneering discoveries in physiology of the late nineteenth and early twentieth century. Why was this work not reviewed by the Nobel Committee? Why was Pflüger's work on glycogen reviewed? Pflüger was extremely influential. Electrophysiology started into a new era, and his experiments triggered much of the work done by other pioneers of electrophysiology, Julius Bernstein, Ernest Overton, Ludimar Hermann, etc. (for more detail, see [9]). Probably none of these fathers of modern electrophysiology were ever considered for a Nobel Prize, although their work was extremely influential on the work of Alan Hodgkin and Andrew Huxley [8] and on that of Erwin Neher and Bert Sakmann [6], all later to be honored. Poor Pflüger! Imagine if he would have been the first Nobel laureate for work in electrophysiology? Would his "Archiv" be more popular? We cannot complain about our journal: It still exists and enjoys a high reputation, but with the highlight of "Pflüger, Nobel Laureate 1908," we probably could have added some exciting and positive remarks in contrast to the sometimes critical views taken of the history of the Nobel Prize [2]. Even if the claim is sometimes challenged that the Nobel Prize is "good for science," it certainly would have been a milestone for our journal as it was after the award was given to Erwin Neher and Bert Sakmann, our Honorary Editors!

Eduard Friedrich Wilhelm Pflüger died on March 16, 1910 in Bonn. We have decided to keep his name for our journal and as this thrilling review describes, his name embodies the splendid traditions of German physiology and almost a Nobel Prize!

\section{References}

1. Bernstein J (1912) Elektrobiologie. Friedrich Vieweg und Sohn, Braunschweig

2. Casadevall A, Fang FC (2013) Is the Nobel Prize good for science? FASEB J 27:4682-4690

3. Catterall WA, Goldin AL, Waxman SG (2005) International union of pharmacology. XLVII. Nomenclature and structure-function relationships of voltage-gated sodium channels. Pharmacol Rev 57:397409

4. Ebbecke U (1933) Zur Lehre vom Elektrotonus. Ergebnisse der Physiologie und experimentellen Pharmakologie. Rev Physiol, Biochem Pharmacol 35:756-826

5. Friedman RM (2001) The politics of excellence: behind the Nobel Prize in science. Times Books, New York

6. Hamill OP, Marty A, Neher E, Sakmann B, Sigworth FJ (1981) Improved patch-clamp techniques for high-resolution current recording from cells and cell-free membrane patches. Pflugers Arch 391: $85-100$

7. Hansson N, Schlich T (2014) A "Life Dedicated to True Science": Eduard Pflüger and the Nobel Prize for Physiology or Medicine. Pflugers Arch. doi:10.1007/s00424-014-1564-5

8. Hodgkin AL, Huxley AF (1952) A quantitative description of membrane current and its application to conduction and excitation in nerve. J Physiol 117:500-544

9. Nilius B (2003) Pflugers Archiv and the advent of modern electrophysiology. From the first action potential to patch clamp. Pflugers Arch 447:267-271

10. Pflügers EFW (1859) Untersuchungen über die Physiologie des Elektrotonus. Hirschwald, Berlin

11. Wade N, Nilius B, Piccolino M (2011) A quest in neurosciences: neuroportraits. Pflugers Arch 461:591-592 